\title{
A systematic literature review of pediculosis due to head lice in the Pacific Island Countries and Territories: what country specific research on head lice is needed?
}

\author{
Rick Speare ${ }^{1,2^{*}}$, Humpress Harrington ${ }^{3}$, Deon Canyon ${ }^{4}$ and Peter D Massey ${ }^{5}$
}

\begin{abstract}
Background: Lack of guidelines on control of pediculosis in the Solomon Islands led to a search for relevant evidence on head lice in the Pacific Island Countries and Territories (PICTs). The aim of this search was to systematically evaluate evidence in the peer reviewed literature on pediculosis due to head lice (Pediculus humanus var capitis) in the $22 \mathrm{PICT}$ from the perspective of its value in informing national guidelines and control strategies.

Methods: PubMed, Web of Science, CINAHL and Scopus were searched using the terms (pediculosis OR head lice) AND each of the 22 PICTs individually. PRISMA methodology was used. Exclusion criteria were: i) not on topic; ii) publications on pediculosis not relevant to the country of the particular search; iii) in grey literature.

Results: Of 24 publications identified, only 5 were included. Four related to treatment and one to epidemiology. None contained information relevant to informing national guidelines.

Conclusions: Current local evidence on head lice in the PICTs is minimal and totally inadequate to guide any recommendations for treatment or control. We recommend that local research is required to generate evidence on: i) epidemiology; ii) knowledge, attitudes and practices of health care providers and community members; iii) efficacy of local commercially available pharmaceutical treatments and local customary treatments; iv) acceptability, accessibility and affordability of available treatment strategies; and iv) appropriate control strategies for families, groups and institutions. We also recommend that operational research be done by local researchers based in the PICTS, supported by experienced head lice researchers, using a two way research capacity building model.
\end{abstract}

Keywords: Head lice, Pediculosis, Pediculus humanus var capitis, Pacific Island Countries and Territories, Systematic literature review, Papua New Guinea, Solomon Islands, French Polynesia

\section{Background}

When the local community at Atoifi in the Solomon Islands decided to control head lice, they could find no national guidelines. This raised the important question of whether countries and their residents need local evidence to control pediculosis, which is a global problem due to Pediculus humanus var capitis [1].

\footnotetext{
* Correspondence: rickspeare@gmail.com

${ }^{1}$ College of Public Health, Medical and Veterinary Sciences, James Cook University, Townsville 4811, Australia

${ }^{2}$ Tropical Health Solutions, 72 Kokoda St, Idalia, Townsville 4811, Australia Full list of author information is available at the end of the article
}

Country-specific data is essential for planning communicable disease control programs, even for pediculosis [2]. For more serious diseases the importance of local data is well established. For example, intestinal parasite control activities have to be informed by country, regional and even locally-specific data collected on a regular basis to determine the local epidemiology and extent of parasitic infections with long-term repeated surveillance to inform strategies as the situation changes [3,4]. Quantitative data can be used in modeling to make disease control more cost-effective; e.g., measles vaccination programs [5] and the HIV Spectrum and Estimation and Projection Package programs [6]. In a similar way country-specific 
and local data arguably can improve control strategies for pediculosis [2]. The value of local research in informing practice was reinforced by a survey in South Africa carried out by the provincial communicable disease program that showed only children of European and Indian ancestry in a mixed race school had pediculosis [7]. This resulted in targeting of Mpumulanga Province's health departmental control efforts for pediculosis away from the black African students to the other racial groups. From a communicable disease control perspective evidence needed to control pediculosis can be placed in several categories: biology, epidemiology, impact, diagnosis, treatment, societal context and policies.

Head lice have been a topic of research since before the $20^{\text {th }}$ century. Initial studies focussed on biology, epidemiology and techniques to kill lice with the emphasis from the 1940s shifting to research on efficacy of pharmaceutical treatments [8-10]. The emergence of insecticide resistance to organochlorines (DDT and BHC) in the 1970s [11], and then to permethrin in the 1990s [12], expanded the search for alternative insecticidal therapies, and exploration of the mechanisms of action of chemically defined insecticides [13]. Accompanying this was research on control strategies at the community level, particularly in the UK, using physical removal of head lice [14]. In the $21^{\text {st }}$ century research on treatments expanded to include topical silicon-based oils [15] and oral ivermectin $[16,17]$. Other research included the psychological effect of pediculosis [18] and beliefs and practices of community members from developed and developing countries [19-21].

Various developed countries have published guidelines for management and control of head lice, largely based on the evidence generated by research. A set of international guidelines provided general guidance across many sectors from government to parents [22]. The importance of local data was emphasised for: 1) understanding the pattern of insecticide resistance against the locally marketed products; 2) epidemiological studies in situations where control is ineffective; 3 ) formulating local recommendations which recognised local cultural factors. The guidelines emphasised the important role of universities and other research institutions in conducting research across the spectrum of pediculosis in their own country.

Although most head lice research is from a developed country perspective, some of the emerging economies, especially in Latin America, Asia and the Middle East, have begun to publish original research. However, head lice research in the developing countries in Africa and Oceania remains rare [2]. The unspoken assumption seems to be that these regions have bigger and more important issues to deal with than pediculosis.

Anecdotal evidence suggests that pediculosis is widespread in the 22 PICTs. However, there appears to be little evidence to support this statement apart from the frequent scene of heads being manually searched and head lice crushed or even eaten (Figure 1).

The biology of head lice (Pediculus humanus var capitis) is the same globally, but the epidemiology varies with society and cultural behaviour. Feasible treatment options are highly context dependent owing to access to pediculocides, affordability and culturally acceptable behaviour (e.g., head shaving). Insecticide resistance patterns globally are correlated with the use of topical insecticides [23], but these are rarely used in poor societies [20]. Since controlling pediculosis is not a simple task, parents experience difficulty in managing the many aspects of pediculosis control $[19,20]$. Head lice guidelines that are practical and tailored to fit each groups' special circumstances can assist parents, often through ensuring that health care providers communicate appropriate and relevant advice.

Pediculosis due to head lice is classified as one of the six Epidermal Parasitic Skin Diseases, an informal subcategory of the Neglected Tropical Diseases [24]. In developing countries, pediculosis appears often to be dismissed as being too minor a problem for health departments faced with managing overwhelming health problems with limited resources. However, the majority of parents and guardians in resource poor countries would arguably prefer feasible options to assist them to manage pediculosis [20].

Since we had difficulty locating evidence to inform local head lice guidelines in the Solomon Islands, we decided to do a systematic literature review of pediculosis in the PICTs. The aim of this review was to evaluate evidence in the peer reviewed literature on pediculosis due to head lice in the 22 nations that form the PICTs.

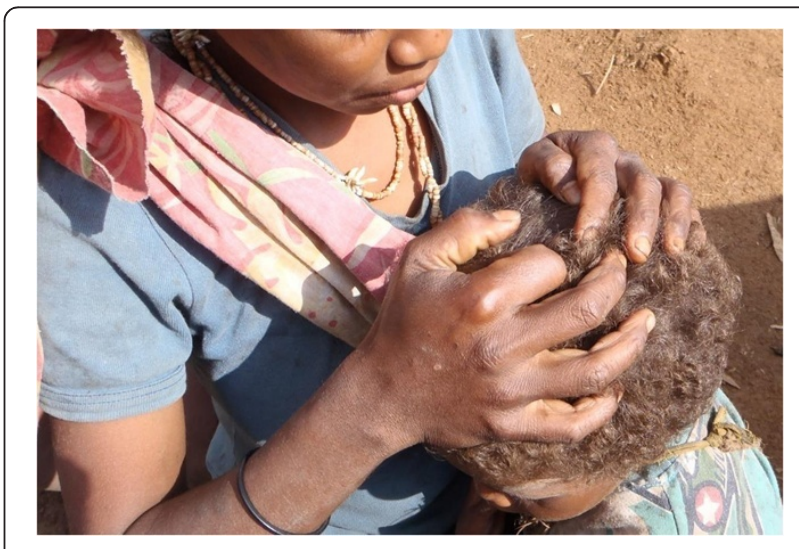

Figure 1 Teenage girl searching for and crushing head lice in a young child (East Kwaio mountains, Malaita Province, Solomon Islands). 


\section{Methods}

The PRISMA methodology was used to search the peer-reviewed literature [25]. Search terms used were (pediculosis OR head lice) AND the following countries individually: (American Samoa), (Cook Islands), Fiji, (French Polynesia), Guam, Kiribati, (Mariana Islands), (Marshall Islands), Micronesia, Nauru, (New Caledonia), Niue, Palau, (Papua New Guinea), Pitcairn, Samoa, (Solomon Islands), Tokelau, Tonga, Tuvalu, Vanuatu, and Wallis. The following electronic databases were searched between 10-22 August 2013: PubMed, CINAHL, Web of Science, Scopus, and Google Scholar. The reference lists of included papers were subsequently searched for additional papers not found by the database searches.

Inclusion criteria were: the topic of the publication was pediculosis or head lice; the report was about one or more of the 22 PICTs. Exclusion criteria were: i) not on topic; ii) publications on pediculosis not relevant to the country of the particular search even if the publication referred to another PICT since this record was captured under the other PICT; iii) no English title or abstract; iv) in grey literature (i.e., not in a peer reviewed journal or a monograph).

Based on titles irrelevant publications were rejected at country search level. Duplicates from different sources were then collapsed at country level. If content appeared relevant, abstracts were considered, non-relevant articles excluded and reasons for exclusion recorded. Full texts of all remaining publications were obtained and assessed.

The nature of the literature was classified as: i) original research, ii) reviews, iii) program descriptions or iv) commentary/discussion paper using an adapted research identification schema with original research further classified as: (i) descriptive; (ii) measurement study; (iii) operations/intervention research [26].

\section{Results}

Five relevant publications were located from an original 28 hits from the database searches (Figure 2). Reasons for rejection of the 19 excluded papers were: i) not on topic $=11$; ii) publications on pediculosis not relevant to the country of the particular search $=8$.

The five included publications originated from three of the 22 PICTs (French Polynesia, Papua New Guinea (PNG), Solomon Islands) and are summarised in Table 1.

The only clinical trial was an unblinded single arm therapeutic trial of the efficacy of oral ivermectin in treating pediculosis in French Polynesia [27]. A large cross-sectional survey reported in 1985 examined 10,244 people in the Western Province of Solomon Islands for skin conditions [28]. It found that pediculosis was "universally present among both sexes and all ages". However, the prevalence of pediculosis was not determined; no additional details were provided. A genetic study on insecticide susceptibility of head lice used a very small sample of 3 lice from PNG [23]. Although it found that insecticide resistance genes were not present in these lice, it was not designed to assess the extent of resistance or decrease in susceptibility (if any) in PNG. Two other studies from PNG dealt with treatment of pediculosis. One was a case report of fatal poisoning from paraquat (a herbicide) misused to self-treat pediculosis [29]. The other was a brief comment that bark of a tree was used in Morobe Province to treat head lice [30]. No evidence on efficacy was provided.

\section{Discussion}

This review found only five publications on pediculosis or head lice from the 22 PICTs. The only epidemiological study was published more than 30 years ago and unfortunately did not quantify the prevalence of pediculosis [28].

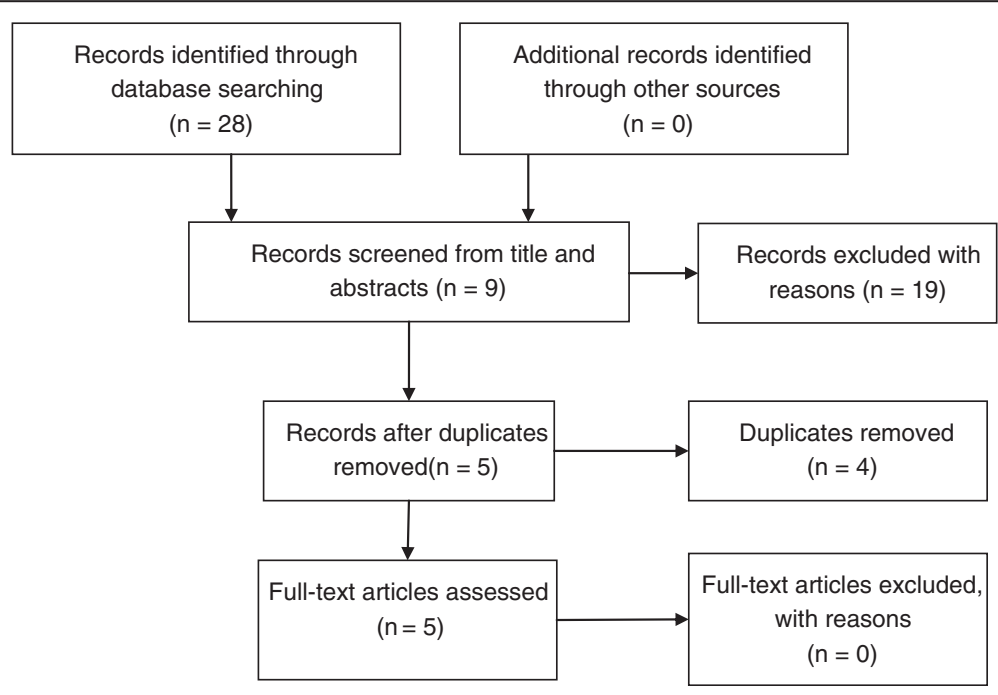

Figure 2 PRISMA flow chart of record retrieval and exclusion. 
Table 1 Publications on head lice or pediculosis in Pacific Island Countries or Territories

\begin{tabular}{|c|c|c|c|c|c|c|}
\hline $\begin{array}{l}\text { Author (year) } \\
\text { citation number }\end{array}$ & Content & $\begin{array}{l}\text { Type of } \\
\text { study }\end{array}$ & Participants & Country & $\begin{array}{l}\text { Classification } \\
\text { of study }\end{array}$ & Comment \\
\hline $\begin{array}{l}\text { Wohlfahrt } \\
\text { (1982) [29] }\end{array}$ & $\begin{array}{l}\text { Death with skin ulceration } \\
\text { and respiratory failure after } \\
\text { self-application of paraquat } \\
\text { to head to treat pediculosis }\end{array}$ & Case report & 1 adult male & $\begin{array}{l}\text { Papua New Guinea } \\
\text { (Western Highlands } \\
\text { Province) }\end{array}$ & $\begin{array}{l}\text { Original } \\
\text { research; } \\
\text { descriptive }\end{array}$ & $\begin{array}{l}\text { No value in } \\
\text { informing local } \\
\text { guidelines }\end{array}$ \\
\hline $\begin{array}{l}\text { Eason \& Tasman- } \\
\text { Jones (1985) [28] }\end{array}$ & $\begin{array}{l}\text { Pediculosis prevalence in } \\
\text { Western Province }\end{array}$ & $\begin{array}{l}\text { Cross sectional } \\
\text { survey }\end{array}$ & $\begin{array}{l}10,224 \text { total }(5,160 \\
<15 \text { years of age })\end{array}$ & $\begin{array}{l}\text { Solomon Islands } \\
\text { (Western Province) }\end{array}$ & $\begin{array}{l}\text { Original } \\
\text { research; } \\
\text { measurement }\end{array}$ & $\begin{array}{l}\text { No value in } \\
\text { informing local } \\
\text { guidelines }\end{array}$ \\
\hline $\begin{array}{l}\text { Glaziou et al. } \\
\text { (1994) [27] }\end{array}$ & $\begin{array}{l}\text { Evaluating the efficacy of oral } \\
\text { ivermectin (single oral dose } \\
\text { of } 0.2 \mathrm{mg} / \mathrm{kg} \text { ) to treat pediculosis }\end{array}$ & $\begin{array}{l}\text { Unblinded } \\
\text { single arm } \\
\text { therapeutic } \\
\text { trial }\end{array}$ & $\begin{array}{l}26 \text { total }-2 \text { males } \\
\& 24 \text { females aged } \\
5-17 \text { years }\end{array}$ & French Polynesia & $\begin{array}{l}\text { Original } \\
\text { research; } \\
\text { intervention }\end{array}$ & $\begin{array}{l}\text { Minimal value in } \\
\text { informing local } \\
\text { guidelines }\end{array}$ \\
\hline $\begin{array}{l}\text { Thomas } \\
\text { (2006) [30] }\end{array}$ & $\begin{array}{l}\text { Ethnomedicine review on use } \\
\text { of bark from Galbulimima tree. } \\
\text { Mixed with tobacco to treat } \\
\text { head lice; no details }\end{array}$ & $\begin{array}{l}\text { Second hand } \\
\text { report }\end{array}$ & No participants & $\begin{array}{l}\text { Papua New Guinea } \\
\text { (Data collected from } \\
\text { Morobe Province) }\end{array}$ & Commentary & $\begin{array}{l}\text { Minimal value in } \\
\text { informing local } \\
\text { guidelines }\end{array}$ \\
\hline $\begin{array}{l}\text { Hodgdon et al. } \\
\text { (2010) [23] }\end{array}$ & $\begin{array}{l}\text { Genetic study of } k d r \text { resistance } \\
\text { genes in head lice from many } \\
\text { countries }\end{array}$ & Louse genetics & $\begin{array}{l}3 \text { lice from } 1 \\
\text { person }\end{array}$ & $\begin{array}{l}\text { Papua New Guinea } \\
\text { (location not given) }\end{array}$ & $\begin{array}{l}\text { Original } \\
\text { research; } \\
\text { measurement }\end{array}$ & $\begin{array}{l}\text { No value in } \\
\text { informing local } \\
\text { guidelines }\end{array}$ \\
\hline
\end{tabular}

Of four papers relevant to treatment of pediculosis, only one was a therapeutic trial [27]. This study demonstrated that lice in French Polynesia could be killed by oral ivermectin with at day 14 elimination of adult lice and nymphs in $100 \%$ and $43 \%$ of subjects respectively. Side effects were minimal, but the study had important limitations. Another paper found no permethrin resistance $(k d r)$ genes in three PNG head lice and the other two treatment papers were case reports. All five reviewed publications have minimal or no value for planning head lice control strategies or informing local guidelines.

One possible limitation to this review is that this systematic review did not include non-peer reviewed literature. However, since the goal was to determine what evidence was available to formulate strategies and guidelines, the focus on peer-reviewed sources would be expected to provide the highest level of evidence available.

If we adopt the perspective of a ministry of health in any country in the PICTs and use the categories of research evidence originally proposed, what country specific data are needed? The international guidelines are useful here, but they recommend further research in all aspects of head lice and their control [22]. The only research topic that is prioritised in the international guidelines is resistance to locally available pharmaceutical products.

We do not consider that research on all aspects of pediculosis control is needed in resource poor countries where research funds and skills are in short supply. The following comments highlight important gaps in understanding in areas where we consider that local research will add useful evidence to guide pediculosis control. Although the comments are targeted towards the PICTs, they possibly have value for other developing countries that do little research on pediculosis.
The biology of head lice is well known and the available knowledge can be assumed to be relevant locally. Research on biology is arguably not required at the country level. Epidemiology is location specific and in the absence of any evidence, making assumptions from another countries' data is unreliable. The impact of pediculosis on individuals is not well known globally, but presumably there will be lower levels of anxiety in people in the PICTs than in developed countries. There is less need to research this aspect. Diagnostic techniques are well researched and this knowledge can be adopted locally in the PICTs. However, which techniques are feasible is influenced by local socio-economic factors. For example, the baseline diagnostic technique in the PICTs is visual census, with access to nit combs and conditioner being uncommon. Detection of lice by use of conditioner and nit comb is the most sensitive diagnostic technique; however, affordability of and access to conditioner and nit combs in the PICTs make this diagnostic technique inaccessible to most. Research is needed on what diagnostic techniques are feasible and acceptable in the PICTs.

Treatment of pediculosis in the PICTs is anecdotally reported to be largely by physical capture of lice (Figure 1), with very limited access to and use of pharmaceuticals. For example, in the Solomon Islands topical 1\% permethrin is available from the Ministry of Health by prescription only. Cost of treatment relative to income is a critical factor in choice of therapy and must be considered as evidence in formulating government recommendations, particularly for societies with low average incomes like in the PICTs. Local research on access to and affordability of commercially available treatments is required. Assumptions on the efficacy of treatments based on research evidence from other countries will be unreliable; hence, local 
research is needed. In addition rural populations have local plant based treatments for pediculosis. These are accessible and inexpensive but local research is needed to test efficacy.

Country specific research on feasible management options for pediculosis is needed. The societal context is highly country specific. How people perceive pediculosis and what they want to do about it determines the feasibility of approaches to management and control [20]. Research is essential on this societal context. Research on effectiveness of policies is also needed. Of course the macro-policies of the ministries of health and education and the micro-policies of individual schools and other institutions should be based on relevant country-specific evidence. However, evaluation of policy interventions is essential and this can only be done by country-specific research. Strengthening the capacity of people within resource poor settings to undertake health research is critical to improving health equity and embedding mutuality throughout the research capacity strengthening process is beneficial [31,32].

\section{Conclusion}

We conclude that there is minimal current local evidence to guide decisions on head lice control in the Pacific Island Countries and Territories. We recommend that basic evidence be generated on: i) epidemiology; ii) knowledge, attitudes and practices of health care providers and community members; iii) efficacy of local commercially available pharmaceutical treatments and local customary treatments; iv) acceptability, accessibility and affordability of available treatment strategies, including non-pharmaceutical measures; and iv) appropriate control strategies for families, groups and institutions. We also recommend that the required research be done by local researchers based in the PICTs, supported by researchers experienced in head lice research, using a two way research capacity strengthening model [30]. The research should have an operational focus to provide results that will assist health decision makers to develop feasible national guidelines and residents of these nations to have access to relevant knowledge and resources to control head lice.

\section{Competing interests}

All authors declare that they have no competing interests.

\section{Authors' contributions}

RS designed the review, carried out the literature search, assessed retrieved papers and drafted the manuscript. HH designed the review, and assessed the retrieved papers. DC assessed the retrieved papers. PM assessed the retrieved papers. All authors contributed to the final manuscript and all read and approved the final manuscript.

\section{Acknowledgements}

This study received financial support from TDR, the Special Programme for Research and Training in Tropical Diseases, co-sponsored by UNICEF, UNDP, the World Bank and WHO (grant 1-811001688) and Tropical Health Solutions Pty Ltd.

\section{Author details}

${ }^{1}$ College of Public Health, Medical and Veterinary Sciences, James Cook University, Townsville 4811, Australia. ${ }^{2}$ Tropical Health Solutions, 72 Kokoda St, Idalia, Townsville 4811, Australia. ${ }^{3}$ Atoifi College of Nursing, Atoifi, Malaita Province, Solomon Islands. ${ }^{4}$ Office of Public Health Studies, University of Hawaii at Manoa, 1960 East-West Rd, Biomed Building \#T103, Honolulu, HI 96822, USA. ${ }^{5}$ Health Protection, Hunter New England Population Health, Tamworth 2340, Australia.

Received: 6 April 2014 Accepted: 20 June 2014

Published: 24 June 2014

\section{References}

1. Gratz NG: Human lice their prevalence, control and resistance to insecticides: a review 1985-1997. Geneva: World Health Organization; 1997.

2. Falagas ME, Matthaiou DK, Rafailidis PI, Panos G, Pappas G: Worldwide prevalence of head lice. Emerg Infect Dis 2008, 14:1493-1494. doi:10.3201/ eid1409.080368.

3. Shin E, Guk S, Kim H, Lee S, Chair J: Trends in parasitic disease in the Republic of Korea. Trends Parasitol 2007, 24:143-150. doi:10.1016/j. pt.2007.12.003.

4. Steinmann P, Utzinger J, Du ZW, Zhou XN: Multiparasitism a neglected reality on global, regional and local scale. Adv Parasitol 2010, 73:21-50. doi:10.1016/S0065-308X(10)73002-5.

5. Simons E, Mort M, Dabbagh A, Strebel P, Wolfson L: Strategic planning for measles control: using data to inform optimal vaccination strategies. J Infect Dis 2011, 204(Suppl 1):S28-S34. doi:10.1093/infdis/jir095.

6. Stover J, Brown T, Marston M: Updates to the Spectrum/Estimation and Projection Package (EPP) model to estimate HIV trends for adults and children. Sex Transm Infect 2012, 88(Suppl 2):i11-i16. doi:10.1136/sextrans2012-050640.

7. Govere JM, Speare R, Durrheim DN: The prevalence of pediculosis in rural South African school children. S Afr J Sci 2003, 99:21-23.

8. Nuttal GHF: The biology of Pediculus humanus. Parasitol 1917, 10:181-185.

9. Buxton PA: The louse: an account of the lice which infest man, their medical importance and control. London: Edward Arnold \& Co; 1947.

10. Busvine JR, Burn JL, Gamlin R: Experiments with DDT and gamma-BHC (Gammexane) for use against head lice. Med Officer 1948, 79:121-127.

11. Maunder JW: Resistance to organochlorine insecticides in head lice, and trials using alternative compounds. Med Officer 1971, 125:27-29.

12. Mumcuoglu KY, Hemingway J, Miller J, loffe-Uspensky I, Klaus S, Ben-Ishai F, Galun R: Permethrin resistance in the head louse Pediculus capitis from Israel. Med Vet Entomol 1995, 9:427-432, 447. PMID:8541597.

13. Heukelbach J, Canyon DV, Oliveira FA, Muller R, Speare R: In vitro efficacy of over-the-counter botanical pediculicides against the head louse Pediculus humanus var capitis based on a stringent standard for mortality assessment. Med Vet Entomol 2008, 22:264-272. doi:10.1111/ j.1365-2915.2008.00738.x.

14. Ibarra J, Fry F, Wickenden C, Jenner M, Franks A: The impact of welldeveloped preventative strategies on the eradication of head lice. Perspect Public Health 2009, 129:165-173. doi:10.1177/1466424008094804.

15. Burgess IF, Brunton ER, Burgess NA: Single application of $4 \%$ dimeticone liquid gel versus two applications of $1 \%$ permethrin creme rinse for treatment of head louse infestation: A randomised controlled trial. BMC Dermatol 2013, 13:5. doi:10.1186/1471-5945-13-5.

16. Currie MJ, Reynolds GJ, Glasgow NJ, Bowden FJ: A pilot study of the use of oral ivermectin to treat head lice in primary school students in Australia. Pediatric Dermatol 2010, 27:595-599. doi:10.1111/j.15251470.2010.01317x

17. Pilger D, Heukelbach J, Khakban A, Oliveira FA, Fengler G, Feldmeier $H$ : Household-wide ivermectin treatment for head lice in an impoverished community: randomized observer-blinded controlled trial. Bull World Health Organ 2010, 88:90-96. doi:10.2471/BLT.08.051656.

18. Parison J, Canyon D, Speare R: Head lice: the feelings people have. Int J Dermatol 2013, 52:169-171. doi:10.1111/j.1365-4632.2011.05300.x.

19. Parison J, Speare R, Canyon DV: Uncovering family experiences with head lice: the difficulties of eradication. Open Dermatol J 2008, 2:9-17. 
20. Heukelbach J, Ugbomoiko US: Knowledge, attitudes and practices regarding head lice infestations in rural Nigeria. J Infect Dis Child 2011, 5:652-657. doi:10.3855/jidc.1746 PMID:21918306.

21. Rukke BA, Birkemoe T, Soleng A, Lindstedt HH, Ottesen P: Head lice in Norwegian households: actions taken, costs and knowledge. PLoS One 2012, 7:e32686. doi:10.1371/journal.pone.0032686.

22. Mumcuoglu KY, Barker SC, Burgess IE, Combescot-Lang C, Dalgleish RC, Larsen KS, Miller J, Roberts RJ, Taylan-Ozkan A: International guidelines for effective control of head louse infestations. J Drugs Dermatol 2007, 6:409-414. PMID:17668538.

23. Hodgdon HE, Yoon KS, Previte DJ, Kim HJ, Aboelghar GE, Leed SH, Clarka $\mathrm{JM}$ : Determination of knockdown resistance allele frequencies in global human head louse populations using the serial invasive signal amplification reaction. Pest Manag Sci 2010, 66:1031-1040. doi:10.1002/ ps.1979.

24. Feldmeier $\mathrm{H}$, Heukelbach J: Epidermal parasitic skin diseases: a neglected category of poverty-associated plagues. Bull World Health Organ 2009, 87:152-159. doi:10.2471/BLT.07.047308.

25. PRISMA: [Internet] PRISMA statement. http://www.prisma-statement.org/.

26. Redman-MacLaren ML, MacLaren DJ, Asugeni R, Fa'anuabae CE, Harrington $H$, Muse A, Speare R, Clough AR: "We can move forward": challenging historical inequity in public health research in Solomon Islands. Inter J Equity Health 2010, 9:25. doi:10.1186/1475-9276-9-25.

27. Glaziou P, Nyguyen LN, Moulia-Pelat JP, Cartel JL, Martin PM: Efficacy of ivermectin for the treatment of head lice (Pediculosis capitis). Trop Med Parasitol 1994, 45:253-254. PMID:7899799.

28. Eason RJ, Tasman-Jones T: Resurgent yaws and other skin diseases in the Western Province of the Solomon Islands. P N G Med J 1985, 28:247-250. PMID:2940770

29. Wohlfahrt DJ: Fatal paraquat poisonings after skin absorption. Med J Aust 1982, 1:512-513. PMID:7099093.

30. Thomas B: Galbulimima bark and ethnomedicine in Papua New Guinea. PN G Med J 2006, 49:57-59. PMID:18396614

31. Mony PK, Kurpad A, Vaz M: Capacity building in collaborative research is essential. Br Med J 2005, 331:843-844. doi:10.1136/bmi.331.7520.843-b.

32. Redman-MacLaren ML, MacLaren DJ, Humpress H, Asugeni R, TimothyHarrington R, Kekeubata K, Speare R: Mutual research capacity strengthening: a qualitative study of two-way partnerships in public health research in Solomon Islands. Int J Equity Health 2012, 11:79. doi:10.1186/1475-9276$11-79$.

doi:10.1186/1471-5945-14-11

Cite this article as: Speare et al:: A systematic literature review of pediculosis due to head lice in the Pacific Island Countries and

Territories: what country specific research on head lice is needed? BMC Dermatology 2014 14:11.

\section{Submit your next manuscript to BioMed Central and take full advantage of:}

- Convenient online submission

- Thorough peer review

- No space constraints or color figure charges

- Immediate publication on acceptance

- Inclusion in PubMed, CAS, Scopus and Google Scholar

- Research which is freely available for redistribution 